УДК $341.18(4-11+477)$

DOI: https://doi.org/10.32782/2413-9971/2019-28-56

\author{
Chornyi Oleh \\ PhD in Philosophy, \\ Post-Doctoral Student of Marketing and Agrarian Business Department \\ Vinnytsia National Agrarian University
}

Чорний О. В. кандидат філософських наук, докторант кафедри маркетингу та аграрного бізнесу Вінницького наиіонального аграрного університету

\title{
CONVERGENCE BETWEEN EASTERN EUROPE AND UKRAINE: THE WAYS OF IMPROVEMENT
}

Summary. This article is devoted to some problems of convergence between Ukraine and the countries of Eastern Europe. It is emphasized that the reforms of recent years are crucial for the acceleration economic development. Particular attention is paid to the various interdisciplinary factors that may accelerate convergence. In the context of this paper, convergence problems are seen as complex interdisciplinary real-world problems. As the problems of convergence are complex, Ukraine should use the invaluable experience of the EU Member States. At the level of economic problems, the greater attention should also be given to the social, cultural and psychological aspects of convergence. Moreover, since real economic development depends on ideology, politics, law and government, it is worth considering in more detail the possibilities of liberal democracy development.

Key words: Eastern Europe, Ukraine, economic development, post-communism, liberalism, interdisciplinarity.

Introduction. Following the 2014 Revolution of Dignity, Ukrainian society has clearly identified its social, political and economic development goals. This means that liberal democracy has been building in Ukraine for more than five years. Last condition will help to facilitate Ukraine's integration into the European Union and the global economy in the future. Many reforms have been launched in recent years, which, from a scientific point of view, are characterized by wide coverage and interdisciplinarity. In this paper, we want to focus on some of the issues that are important for the acceleration of convergence between Ukrainian and Eurozone economies.

It is well known that the improvement of economic indicators are crucial for the economic development. But other related factors in different spheres of public life are also important. Given the fact that convergence itself is characterized by broad interdisciplinarity, we would like to draw attention to legal, political and ideological factors of convergence in the course of our work. Particular attention is paid to the 
problems of law, politics, the post-socialist past and opportunities of the liberal democracy development.

Literature overview. Convergence is the equalization of development. In other words it is when developing countries grow faster than developed countries. Effective economic policies must be pursued in order to stimulate economic development. First of all, it should be noted that economic reforms and improvements must have permanent character [1]. For example, economic improvements may include a reduction of public debt [2] or an increase in foreign direct investment flows caused by various government improvements [3] Changes in a national tax system caused by globalization and international competition are also important [4]. These economic changes and improvements are crucial, but economic-related factors can also have a significant effect.

Economic-related factors may include establishment of ethics and shared values, development of civil society and increased confidence in government. Along with these factors, modernization of education system and increase in educational level of population may play a great role [5]. Just like education, a level of technological development or technological backwardness of a country can have a serious impact on a course of economic processes and economic growth [6]. However, the most important type of reforms is structural reforms. It can result in a change of an old system to a new one. These reforms may include restructuring and improvement in many areas of a country's life. Such reforms may relate to players' ethics, anti-corruption, judiciary and government decisions [7]. Given the breadth of the issue, problems of convergence between Ukraine and Eastern European countries are complex and have clear interdisciplinary character.

The aim of the paper is to reveal interdisciplinary specifics of convergation processes between Ukraine and Eastern European countries.

Results of the research. Since the economies of Eastern European countries is part of the Eurozone economy, the convergence between them and Ukraine is a part of a broader process - globalization of the Ukrainian economy. Integration of a national economy into the global economic system is possible only if an economy is open [8]. An open economy is characterized by many things, so a policy that helps to change the orientation of a national economic system should be complex and multifaceted. In Ukraine, such a transition has actually taken place for almost thirty years. However, the reduction of protectionism has a positive effect. An additional factor may be an increase in the level of cross-industry trade, since such correlation is distinct characteristic of the world's most open economy - the USA [9]. A radical change in economic strategy can be applied not only to Ukraine, but also to the Eurozone itself [10]. That is why, in order to increase convergence, Ukraine can use the existing strategies. Increase in the level of economic openness can attract new investors and show a direction to regional and global markets. However, it is only one side of economic development. On the other hand, Ukrainian officials need to focus on the process of society development and the specifics of change. This direction creates an opportunity to accelerate politics, governance and public administration discourses implementation, make them nationally-specific in order to spur economic development.

Politicians need to focus on specific effective reforms, but they should also know an experience of other countries and a theory itself. First of all, it should be understood that development (including economic) is a multidimensional process that involves different aspects of people's lives improvement [11] The complexity of country's development concerns not only an improvement of material living conditions, but also moral and spiritual aspects. This means that sociology, cultural studies, psychology and religious studies should be used in conjunction with economic theory, public administration and political science. Secondly, development requires the ability to generate change constantly, which is especially important for former socialist economies [12]. For the countries such as Ukraine, it is worth developing the ability to conduct serious reforms and small improvements continually. This precisely characterize the situation in developed countries, because a progress is a continuous development. Thirdly, Ukraine's economic development, as well as its convergence with the Eurozone, is a long-term process. European integration processes have begun 60 years ago [13], and over time, the European Union's emphasis on the real convergence has only intensified [14]. Finally, actual development of strong political institutions is considered even more important than a development of economic institutions for post-communist countries [15]. This is the general paradigm of a development for the most of post-socialist European countries, including Ukraine. Of course, the list is not exhaustive, but all four elements are important components of Ukraine's development.

The convergence between Ukraine and Eastern Europe is part of a broader process, namely the rapprochement of Ukraine with the EU, as Ukraine intends to become the EU member. Therefore, the material of this article can be viewed as referring to the convergence between Ukraine and the EU. Taking this aspect into account, the interdisciplinary complexity of convergence only increases. Real world problems are often differ from what is written in formalized scientific textbooks. Universities teach fragmented academic disciplines, while in the real world there is a need for effective integration of knowledge from various fields. Further, such complex integration of knowledge can be effective, if professionals and scientists from different fields work together to solve complex real problems. The problems of convergence acceleration require structural, and therefore complex, reforms, which should be of a lasting and permanent nature. The number of academic disciplines involved in the state life reforming is overwhelming and may correlate with all national scientific discourse cultivated as fragmented disciplines in Ukrainian universities. In particular, it is necessary to take into account the scientific problems that are being studied in classical, technical, medical, agrarian, pedagogical, law and other Ukrainian universities. Particular attention should be paid to the formation of a relevant outlook within Ukrainian population. This task requires a focus on two major issues: rethinking the communist past and building a liberal democracy.

Acceleration of convergence between the countries of Eastern Europe and Ukraine may be facilitated by the realization of the fact that they share a common past. Attention should be paid to the aspirations of both parties to build liberal democracies with a developed market economy. Therefore, it is worth paying attention to these two aspects concerning the past and the future of Eastern Europe.

The process of Eastern European countries integration into the EU has begun relatively recently. Although the transformation of the planned economy in many post-socialist countries began in the late 1980s, their accession to the European Union (EU) began only in 2004 [16]. The first members of EU were united in 1957, so the whole process can be considered quite lengthy, in fact, it has been going on for over 60 years. This means that Ukraine does not have to rely on affective illusions and vain hopes. Ukraine needs to make constant and significant efforts to change the remnants of a planned economy from within. These processes are, and should be, longterm and structural.

According to Yang \& Grigorescu [16], the stability of Western Europe's economic system has reached maturity. 
At the same time, the economic systems of Eastern European countries continue to evolve and improve. Therefore, there is a situation where the EU member states from Eastern Europe have already reached the level of continuous improvement, while Ukraine still needs to work on this (see above). Ukraine's achievements over the last five years are important, as this is a good start for structural reforms. However, in 2019, the presidential and parliamentary elections took place in Ukraine, which means that continuation of reforms and their structural character will depend on new president and parliament. Of course, some variation, modification and even redirection in the course of reforms implementation is possible, but it is important to keep the pace of reforms and their structure.

It must be mentioned that the situation of change, integration and convergence is not always straightforward. For example, according to Romanian scientists, the situation in Romania in 2016 «did not impress anyone» [17]. Since Romania is a member of the EU, changes in the global economic space and the EU economic space are important for its growth. More specifically, Romania needs resources (economic, political, managerial, cultural, etc.) to respond to changes in the external economic environment.

That was a brief overview of communist past. And now we will focus on the spread of liberal ideas in Eastern Europe.

Ukraine's integration into the EU is a complex and argumentative issue. In simple words, it depends on the direction of economic and political orientation of development that Ukraine will choose. As Ukraine needs to be consistent about this orientation in the long term perspective, it is better to consider the opportunities that will contribute to the development of a market economy. One of these opportunities is the development of liberal democracy as a basis for a market economy, a growth of wealth and a development of strong middle class.

The literature on the development of liberal democracy in Europe is quite diverse. For example, scientists from the Czech Republic, Sima and Nikodym, claim that in most European countries liberal thought is marginalized and underdeveloped [18]. They also claim that in the Czech Republic liberalism is one of the most competitive political trends. But if we refer to the English version of Wikipedia, we find that liberal democracy is the dominant political ideology in Belgium, Denmark, the Netherlands, Norway, Spain, England, France, Italy, Germany and Ireland, and these are the 10 most developed European countries. Perhaps the authors were referring to the spread of liberalism in Eastern Europe. However, the latter is a debatable issue, so it is important for us to determine whether liberal democracy is an acceptable option for political ideology of Ukraine.

It is known that liberal thought in Europe began to develop in the nineteenth century. The first schools at that time were Austro-Hungarian, French and German schools [19]. At that time, scholars and politicians from all over the Europe, sympathetic to the ideas of liberal democracy, were studying in the above mentioned countries. This means that, at least in some
European countries, the liberal tradition has a relatively long history, sufficient to be one of the dominant political ideologies.

In current conditions, Ukraine can use the example of Poland, because in Poland, as well as in Ukraine, liberal thought was quite poorly developed in the twentieth century [20]. However, at present the ideas of liberal economy development are particularly supported by civil society and academia in Poland. Given this, public institutions may also contribute to the development of liberal discourse. This would be a positive factor, both for Ukraine's economic development and for enhancing convergence with the most developed EU member states.

If we look through the last five years of socio-economic reforms, we must say that the direction of the Ukrainian economic system development has already been chosen. There is no doubt about the need to develop a market economy within the geographical boundaries of modern Ukraine. Moreover, the latter is confirmed by more than three decades of scientific works of Ukrainian academic community in the field of economics. However, five years ago, the question of liberal democracy development was questionable; the alternative was contained in focus on relations strengthening with Ukraine's eastern neighbor. After the 2013-2014 Revolution of Dignity, this possibility seems to have been rejected. Therefore, the previous Ukrainian government was doing everything it could to accelerate rapprochement with the EU, both economically, politically and culturally. It seems that if the current leadership of Ukraine continues the reforms of the previous government, it is likely that the values of liberal democracy will be upheld in Ukraine. Such a factor will be positive, as liberal democracy is a political ideology that perfectly complements the development of a market economy, which is a complex interdisciplinary issue. If Ukrainian scientists, in the fields of political science and economics, can come to a consensus on these issues, then it will be possible to talk about the popularization and diffusion of scientific discourse related to the development of liberal democracy. Still, there exist numerous other spheres of work that must be done.

The implementation of the EU-Ukraine Association Agreement is a good example of how convergence occurs in practice. In order to make a brief analysis of the Agreement interdisciplinary complexity, we conducted a research of the reforms implementation plan that is aimed on stabilization and acceleration of Ukraine's development (Table 1).

The table shows that the spheres of the Ukrainian government work are numerous (more than 20 spheres), so Agreement implementation is complex and long-lasting. It should be borne in mind that these areas constitute the basis, but acceleration of convergence requires the united work of all stakeholders in order to achieve the common goal.

Conclusions. The possibility of convergence between Ukraine and Eastern European countries, as well as its effectiveness, depends on many factors and it is a complex interdisciplinary problem by the nature. The issue of convergence is a problem of economics and political science. But convergence also concerns the possibilities of integration into the

Table 1

The directions of work concerning Association Agreement

\begin{tabular}{|c|c|c|c|}
\hline \multicolumn{4}{|c|}{ Scientific perspective on the directions of work concerning Association Agreement } \\
\hline Freedom, Law and Justice & Technical Barriers in trade & Entrepreneurship & Politics and Defense \\
\hline Medicine & Tax System & Energetics & Humanitarian Policy \\
\hline Agriculture & Education and Youth & Financial Sector & State Procurements \\
\hline Science and Innovations & Statistics and Information & Transport and Post Services & Social and Labor Policies \\
\hline State Finances & Environment & Custom Service & Resources Efficiency \\
\hline Sanitation & Smuggling, Fraud and Corruption & Consumers Protection & Intellectual Property \\
\hline
\end{tabular}

Source: [21] 
global economic space, as well as changes in cultural and civic life. The prospects for further research are contained in the development of a discussion around the problems of the liberal ideology spread in Ukraine, as well as in the discussion of possible alternatives or complementary models that can be productive. An increased attention should be paid to complex interdisciplinary nature of convergence processes and structural reforms.

\section{References:}

1. Xu G. (2011) Growth accelerations revisited. Econ Journal Watch, vol. 8, no. 1, pp. 39-56.

2. Bidzo M.M. (2018) Public debt and economic growth: a scissor effect in developing countries? The case of Gabon. Modern Economy, no. 9, pp. 1672-1686. https://doi.org/10.4236/me.2018.910106.

3. Dudić B., Dudić Z., Smoleň J., Mirković V. (2018) Support for foreign direct investment inflows in Serbia. Economic Annals-XXI, no. $169(1-2)$, pp. 4-11.

4. Luković S. (2015) The impact of globalization on the characteristics of European countries' tax systems. Economic Annals, vol. LX, no. 206, pp. 117-139. https://doi.org/10.2298/EKA1506117L.

5. Pal'ová D., Vejačka M. (2018) Analysis of employment in EU according to Europe 2020 Strategy Targets. Economics and Sociology, vol. 11, no. 3, pp. 96-112. https://doi.org/10.14254/2071-789X.2018/11-3/6.

6. Brahim M., Dupuch S. (2016) Foreign direct investments in Europe: are the East-West differences still so noticeable? The European Journal of Comparative Economics, vol. 13, no. 1, pp. 37-61.

7. Arestis Ph., Bárcena-Martín E., Pérez-Moreno S. (2018) Differences in institutional quality across Euro Area Countries: which factors contribute most to inequality? Panoeconomicus, vol. 65, no. 3, pp. 363-379. https://doi.org/10.2298/PAN1803363A.

8. Wielki J., Sytnik I., Sytnik B. (2018) Analysis of the openness level and EU integration trends in the development of Polish economy. Journal of International Studies, vol. 11, no. 2, pp. 267-287. https://doi.org/10.14254/2071-8330.2018/11-2/18.

9. Ferreira-Lopes A., Sousa C., Carvalho H., Crespo N. (2017) Trade protectionism and intra-industry trade: a USA - EU comparison. Research in World Economy, vol. 8, no. 2, pp. 88-102.

10. Ginzburg A., Simonazzi A. (2017) Out of the crisis. A radical change of strategy for the Eurozone. The European Journal of Comparative Economics, vol. 14, no. 1, pp. 13-37.

11. Jeníček V. (2016) Economic growth in the development economy. Agricultural Economics, vol. 62, no. 2, pp. 93-99. https://doi.org/10.17221/234/2014-AGRICECON.

12. Butabaev R. (2015) There is no growth without change: policy implications for transition economies. Montenegrin Journal of Economics, vol. 11, no. 1, pp. 69-84.

13. Herzog B. (2018) Reforming the Eurozone: assessment of the Reform Package by the European Commission - treating symptoms or root causes? Economics and Sociology, vol. 11, no. 3, pp. 59-77. https://doi.org/10.14254/2071-789X.2018/11-3/4.

14. Chapman Sh.A. (2013) Specialization and agglomeration patterns in Eastern Europe. The European Journal of Comparative Economics, vol. 10, no. 1, pp. 49-79.

15. Tamilina L., Tamilina N. (2017) Heterogeneity in institutional effects on economic growth: theory and empirical evidence. The European Journal of Comparative Economics, vol. 11, no. 2, pp. 205-249.

16. Yang X., Grigorescu A. (2017) Measuring economic spatial evolutional trend of Central and Eastern Europe by SDE method. Contemporary economics, vol. 11, no. 3, pp. 253-266.

17. Lupu N. (2016) Will Romania be capable in 2020 to keep the pace with the European Union? Economy Transdisciplinarity Cognition, vol. 19, no. 1, pp. 7-12.

18. Síma J., Nikodym T. (2015) Classical liberalism in the Czech Republic. Econ Journal Watch, vol. 12, no. 2, pp. $274-292$.

19. Prokopijević M., Tasić S. (2015) Classical liberal economics in the ex-Yugoslav Nations. Econ Journal Watch, vol. 12, no. 2, pp. 260-273.

20. Machaj M. (2015) Liberal economics in Poland. Econ Journal Watch, vol. 12, no. 2, pp. 233-241.

21. Agreement pulse (2019) Monitoring of the Action Plan implementation concerning Association Agreement. Available at: http://pulse.eu-ua.org/ua/current-progress (accessed 29 November 2019).

\section{КОНВЕРГЕНЦІЯ МІЖ СХІДНОЮ ЄВРОПОЮ ТА УКРАЇНОЮ: ШЛЯХИ ВДОСКОНАЛЕННЯ}

Анотація. Статтю присвячено окремим проблемам конвергенції між Україною та країнами Східної Європи. Наголошено на тому, що реформи останніх років є вкрай важливими для пришвидшення економічного розвитку. Окрему увагу приділено різним міждисциплінарним чинникам, що можуть пришвидшити конвергенцію. У межах даної роботи проблеми конвергенції розглядаються як складні міждисциплінарні проблеми реального світу. У межах академічних установ розглядаються окремі аспекти реальних проблем, що належать до сфери компетенції конкретних наукових галузей, проте в реальності часто буває так, що проблеми виходять за межі компетентності якоїсь конкретної науки, тому їх називають міждисциплінарними. Оскільки проблеми конвергенції є складними, то Україні варто використовувати безцінний досвід країн - членів Свропейського Союзу. Нарівні з економічними проблемами варто також приділити посилену увагу соціальним, культурним, психологічним та релігійним аспектам конвергенції. Крім того, оскільки реальний економічний розвиток залежить від ідеології, політики, права та державного управління, варто детальніше розглянути можливості розвитку ліберальної демократії. Робота над загальною теорією ліберальної демократії та розроблення специфіки імплементації цього глобального дискурсу до українських умов є одними з ключових елементів прогресивних перетворень. На науковому рівні потрібна посилена співпраця між політологами та економістами, управлінцями та фінансистами, культурологами та психологами, іншими спеціалістами з різноманітних галузей науки. Проблеми, розглянуті в статті, $є$ складовою частиною ширшої проблематики, що має пряме відношення до практичних кроків відносно зближення між Україною та ЄС. У кінці статті здійснено короткий аналіз міждисциплінарної складності реформ, пов’язаних із конвергенцією, та визначено необхідні напрями роботи українського уряду. Моніторинг реалізації плану заходів з виконання Угоди про асоціацію, запущений урядом України восени 2019 р., дає можливість зрозуміти, що конвергенція між Україною та ЄС є надскладним, довготривалим і міждисциплінарним процесом.

Ключові слова: Східна Європа, Україна, економічний розвиток, посткомунізм, лібералізм, міждисциплінарність. 


\section{КОНВЕРГЕНЦИЯ МЕЖДУ ВОСТОЧНОЙ ЕВРОПОЙ И УКРАИНОЙ: ПУТИ СОВЕРШЕНСТВОВАНИЯ}

Аннотация. Статья посвящена некоторым проблемам конвергенции между Украиной и странами Восточной Европы. Подчеркивается, что реформы последних лет крайне важны для ускорения экономического развития. Особое внимание уделено различным междисциплинарным факторам, которые могут ускорить конвергенцию. В рамках данной работы проблемы конвергенции рассматриваются как сложные междисциплинарные проблемы реального мира. Поскольку проблемы конвергенции являются сложными, то Украине стоит использовать бесценный опыт стран - членов Европейского Союза. Наравне с экономическими проблемами следует также уделять повышенное внимание социальным, культурным и психологическим аспектам конвергенции. Кроме того, поскольку реальное экономическое развитие зависит от идеологии, политики, права и государственного управления, стоит детальнее рассмотреть возможности развития либеральной демократии.

Ключевые слова: Восточная Европа, Украина, экономическое развитие, посткоммунизм, либерализм, междисциплинарность. 